Zeszyty Naukowe Szkoły Głównej Gospodarstwa Wiejskiego w Warszawie Problemy Rolnictwa Światowego tom 17 (XXXII), zeszyt 2, 2017: 176-185

DOI: 10.22630/PRS.2017.17.2.37

Luiza Ossowska ${ }^{1}$, Dorota Janiszewska ${ }^{2}$

Politechnika Koszalińska

\title{
Sytuacja na rynku pracy na obszarach wiejskich państw Unii Europejskiej
}

\section{Situation on the Labour Market in Rural Areas of the EU Countries}

\begin{abstract}
Synopsis. Celem badań jest omówienie zróżnicowania państw Unii Europejskiej na podstawie wybranych wskaźników z zakresu rynku pracy obszarów wiejskich. Dane liczbowe pochodzą z 2015 roku (porównawczo z 2013 roku). Badanie przeprowadzono za pomocą analizy skupień. Do analizy przyjęto następujące cechy diagnostyczne: udział osób zatrudnionych w ogólnej liczbie ludności w wieku 20-64, udział osób bezrobotnych w wieku 15-74 w ogólnej liczbie osób aktywnych zawodowo, udział osób bezrobotnych w wieku 15-24 w ogólnej liczbie ludności aktywnej zawodowo oraz produktywność pracy. W wyniku zastosowania analizy skupień podzielono badane państwa na pięć grup.
\end{abstract}

Słowa kluczowe: rynek pracy, obszary wiejskie, państwa Unii Europejskiej

\begin{abstract}
The main objective of this article is to discuss the diversity of European Union countries based on selected indicators of labour market in rural areas. Presented data come from 2015 (in comparison with 2013). The analysis was conducted using the cluster analysis. The following diagnostic features were used for the analysis: employment persons as a share of total 20-64 y. o. population, unemployment rate for the age group 15-74 in total active population, youth unemployment rate for the age group 15-24 in total active population and labour productivity. As a result of the cluster analysis examined regions were divided into five groups.
\end{abstract}

Key words: labor market, rural areas, European Union countries

\section{Wprowadzenie}

Niemal od początku istnienia Unii Europejskiej starano się wypracować wspólne założenia odnoszące się do kluczowej sprawy jaką jest rynek pracy. Problematykę zatrudnienia w Unii Europejskiej poruszano już w Białej Księdze dotyczącej wzrostu gospodarczego, konkurencyjności i zatrudnienia w 1993 roku (European Commission, 1994). W trakcie szczytu lizbońskiego (2000 rok) w zakresie zatrudnienia przyjęto ogólny cel zakładający podniesienie wskaźnika zatrudnienia do $70 \%$ oraz zwiększenie stopy zatrudnienia wśród kobiet do ponad $60 \%$ do 2010 roku. Natomiast w 2003 roku została przyjęta nowa strategia $\mathrm{w}$ dziedzinie zatrudnienia - Europejska strategia petnego zatrudnienia i lepszej pracy dla wszystkich - w której określono trzy nowe cele: osiagnięcie pełnego zatrudnienia, polepszenie jakości i wydajności pracy oraz wzmocnienie spójności

${ }^{1}$ dr, Katedra Polityki Ekonomicznej i Regionalnej Politechnika Koszalińska, ul. Kwiatkowskiego 6E, 75-343 Koszalin, e-mail: luiza.ossowska@tu.koszalin.pl

${ }_{2}$ dr, Katedra Polityki Ekonomicznej i Regionalnej Politechnika Koszalińska, ul. Kwiatkowskiego 6E, 75-343 Koszalin, e-mail: dorota.janiszewska@tu.koszalin.pl 
i integracji społecznej (European Parliament, 2010). Problemy o charakterze strukturalnym spowodowały, że pojawiła się konieczność rewizji strategii lizbońskiej i w 2005 roku został przyjęty Zintegrowany pakiet wytycznych na rzecz wzrostu i zatrudnienia (na lata 20052008), w którym połączono ogólne wytyczne dla polityki gospodarczej z dyrektywami w sprawie zatrudnienia. Pakiet ten obejmuje 23 wytyczne w tym $8 \mathrm{z}$ nich dotyczy zatrudnienia (Komunikat Komisji, 2005). W latach 2008-2010 pakiet ten został utrzymany (Komunikat Komisji, 2007).

W obliczu kryzysu gospodarczego oraz fiaska odnowionej strategii lizbońskiej w 2010 roku decyzją Rady Unii Europejskiej (Council Decision, 2010) pojawiły się nowe wytyczne dotyczące polityki zatrudnienia:

- Wytyczna 7: zwiększenie uczestnictwa kobiet i mężczyzn na rynku pracy, ograniczenie bezrobocia strukturalnego i promowanie jakości zatrudnienia.

- Wytyczna 8: Rozwijanie zasobów wykwalifikowanej siły roboczej odpowiadającej potrzebom rynku pracy oraz promowanie uczenia się przez całe życie.

- Wytyczna 9: Poprawa jakości i wydajności systemów kształcenia i szkolenia na wszystkich poziomach oraz zwiększanie liczby osób podejmujących studia wyższe lub ich odpowiedniki.

- Wytyczna 10: Promowanie włączenia społecznego i zwalczania ubóstwa.

Zalecenia te stały się punktem odniesienia dla nowej strategii Europa 2020, która była odpowiedzią na zmieniającą się sytuację wynikającą $\mathrm{z}$ kryzysu ekonomicznego, globalizacji, rosnącego zapotrzebowania na ograniczone zasoby oraz starzenia się społeczeństw. W jej ramach wytyczono pięć nadrzędnych celów. W zakresie rynku pracy Komisja Europejska do 2020 założyła, iż wskaźnik zatrudnienia osób w wieku 20-64 lat powinien wynosić $75 \%$. W powiązaniu z rynkiem pracy jest również cel, w którym zakłada się ograniczenie liczby osób przedwcześnie kończących naukę szkolną o $10 \%$, zwiększenie do $40 \%$ liczby osób z młodego pokolenia $\mathrm{z}$ wyższym wykształceniem oraz zmniejszenie liczby osób zagrożonych ubóstwem i wykluczeniem społecznym o co najmniej $20 \mathrm{mln}$ (European Commission, 2010).

Istotne znaczenie dla kształtu obecnej polityki zatrudnienia w Unii Europejskiej ma również zainicjowany w 2012 roku przez Komisję Europejską Pakiet na rzecz zatrudnienia, który opiera się na Programie na rzecz nowych umiejętności i zatrudnienia w ramach strategii Europa 2020 (Frączek, 2015). Pakiet ten ma na celu głównie wspieranie tworzenia miejsc pracy, przywrócenie rynkom pracy dynamiki oraz usprawnienie zarządzania w zakresie zatrudnienia na poziomie UE (European Commision, 2012).

W artykule poddano analizie sytuację na rynku pracy obszarów wiejskich państw Unii Europejskiej, zakładając, że na podstawie wybranych wskaźników można wyodrębnić kilka charakterystycznych grup krajów. Warto przy tym dodać, że - jak podają Tocco, Davidova i Bailey (2012) sytuacja na rynku pracy na obszarach wiejskich jest inna niż w miastach. W wielu krajach jest trudniejsza, m.in. $\mathrm{z}$ uwagi na poziom i strukturę zatrudnienia, a także zjawisko bezrobocia. 


\section{Cel i metoda badań}

Celem badań jest omówienie zróżnicowania państw Unii Europejskiej ${ }^{3}$ na podstawie wybranych wskaźników z zakresu rynku pracy obszarów wiejskich. Dane, na podstawie których dokonano analizy, pochodzą z publikacji: Cap context indicators 2014-2020 edycji 2016 (European Commission, 2016). Analizę zróżnicowania badanego zjawiska przeprowadzono dla 2015 roku $^{4}$, uwzględniając obszary wiejskie państw Unii Europejskiej, zgodnie z typologią Eurostatu obejmujących podregiony przeważająco wiejskie (zob. GUS, 2016). Dodatkowo wartości wskaźników cząstkowych (poza produktywnością pracy) porównano do 2013 roku.

Zróżnicowanie sytuacji na rynku pracy obszarów wiejskich państw UE zbadano za pomocą analizy skupień. W badaniach posłużono się tzw. odległością euklidesową, rozumianą jako funkcja podobieństwa, stosując formułę (Parysek, Wojtasiewicz, 1979):

$$
d_{i k}=\sqrt{\sum_{j=1}^{m}\left(x_{i j}-x_{k j}\right)^{2}},
$$

gdzie: $\mathrm{d}_{\mathrm{ik}}$ - odległość pomiędzy i-tym i k-tym obiektem (dla i $\left.=\mathrm{k}=1,2, \ldots, \mathrm{n}\right), \mathrm{x}_{\mathrm{ij}}$ - wartość j-tej zmiennej dla i-tego obiektu (dla $\mathrm{j}=1,2, \ldots, \mathrm{m}), \mathrm{x}_{\mathrm{kj}}$ - wartość $\mathrm{j}$-tej zmiennej dla ktego obiektu.

Do obliczeń wykorzystano zmienne standaryzowane.

Funkcja podobieństwa stanowi podstawę przeprowadzania operacji tworzenia skupień na zasadzie grupowania. W pracy wykorzystano metodę tworzenia skupień J.H. Warda, polegającą na łączeniu tych skupień, które jako całość zapewniają minimum sumy kwadratów odległości od środka ciężkości nowego skupienia, które tworzą (Parysek, Wojtasiewicz, 1979).

$\mathrm{W}$ analizie uwzględniono cztery cechy diagnostyczne dotyczące rynku pracy na obszarach wiejskich w państwach Unii Europejskiej:

- udział osób zatrudnionych w ogólnej liczbie ludności w wieku 20-64 (w \%),

- udział osób bezrobotnych w wieku 15-74 w ogólnej liczbie osób aktywnych zawodowo (w \%),

- udział osób bezrobotnych w wieku 15-24 w ogólnej liczbie ludności aktywnej zawodowo (w \%),

- produktywność pracy (w EUR/osobę),

Wskaźniki wybrano na podstawie analizy wytycznych polityki zatrudnienia Unii Europejskiej. Pierwszy wskaźnik uwzględniono, gdyż obrazuje stopę zatrudnienia w poszczególnych państwach członkowskich, a jak wspomniano wcześniej celem polityki UE jest możliwie pełne zatrudnienie. Wzrost zatrudnienia powinien przebiegać równolegle z przyśpieszeniem tempa wzrostu i wydajności pracy, dlatego też $\mathrm{w}$ analizie uwzględniono jej produktywność. Celem polityki zatrudnienia w UE jest również wzmocnienie spójności społecznej i integracji. W ramach tego celu wskazuje się na podjęcie zdecydowanych działań w zakresie integracji społecznej, w tym głównie zapobiegania wyłączaniu z rynku

\footnotetext{
${ }^{3} \mathrm{Z}$ analizy wykluczono Cypr, Maltę oraz Luksemburg.

${ }^{4} \mathrm{Z}$ uwagi na brak danych dla roku $2015 \mathrm{w}$ przypadku wskaźnika produktywności pracy dane pochodzą z $2013 \mathrm{r}$.
} 
pracy, stąd w analizie uwzględniono odsetek ludności bezrobotnej w ogólnej liczbie ludności aktywnej zawodowo (zob. Szaban, 2016).

\section{Wyniki}

W państwach Unii Europejskiej udział osób zatrudnionych w ogólnej liczbie ludności w wieku 20-64 waha się od 56,7\% do 81,9\%, natomiast średnio w państwach Unii Europejskiej ukształtował się na poziomie $69,6 \%$ (rys. 1). Najwyższe wartości analizowanego wskaźnika odnotowano na obszarach wiejskich Szwecji $(81,9 \%)$, Niemczech $(81,1 \%)$, Holandii $(79,6 \%)$, Wielkiej Brytanii $(79,4 \%)$ oraz Austrii $(77,6 \%)$. Natomiast zdecydowanie niższy udział osób zatrudnionych odnotowano na obszarach wiejskich Bułgarii (56,7\%), Chorwacji (57,1\%), Hiszpanii (58,4\%), Grecji (58,6\%) oraz Włoszech $(59,6 \%)$. Porównując sytuację pod względem odsetka osób zatrudnionych w ogólnej liczbie ludności w wieku 20-64 w 2015 roku do 2013 (tab. 1) roku w państwach Unii Europejskiej odnotowano korzystny trend wzrostowy. Średni wzrost w zakresie analizowanego wskaźnika ukształtował się na poziomie 1,9 p.p. Największy wzrost odnotowano $\mathrm{w}$ państwach o niższym udziale zatrudnionych w ogólnej liczbie ludności w wieku 20-64 (poniżej 70\%), tj.: na Węgrzech - 5,5 p.p., w Portugalii - 3,3 p.p., Estonii 3,3 p.p., na Litwie $-3,2$ p.p., Bułgarii $-3,2$ p.p. oraz na Łotwie $-3,0$ p.p. Natomiast trzy państwa w Unii Europejskiej odnotowały nieznaczny spadek odsetka zatrudnionych, tj.: Finlandia $-0,3$ p.p., Austria -0,3 p.p. oraz Francja - 0,2 p.p.

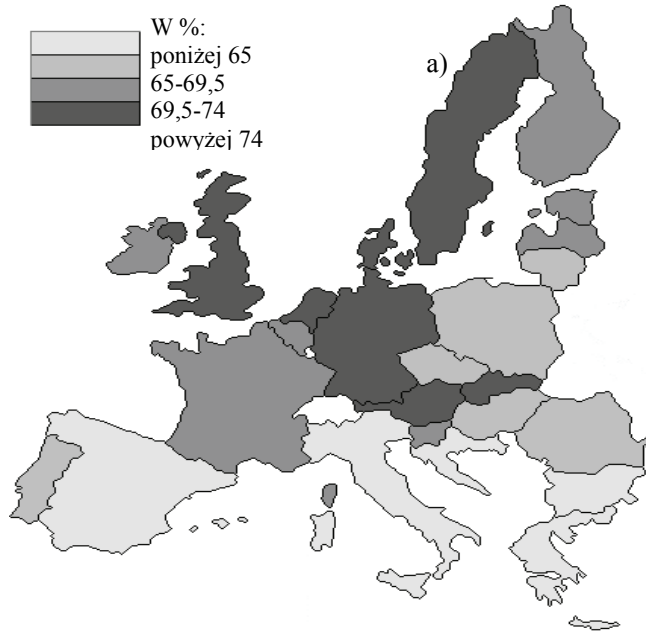

Rys.1. Udział osób zatrudnionych w ogólnej liczbie ludności w wieku 20-64 na obszarach wiejskich państw UE w 2015 roku;

Fig. 1. Employment persons as a share of total 2064 years old population in rural areas EU in 2015

Źródło: obliczenia własne na podstawie: European Commission, 2016.

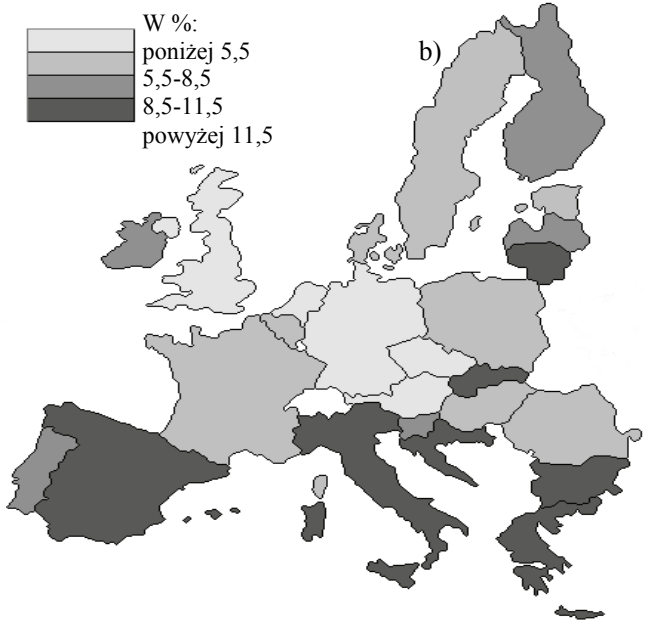

Rys. 2. Udział osób bezrobotnych w wieku 15-74 w ogólnej liczbie osób aktywnych zawodowo na obszarach wiejskich państw UE w 2015

Fig. 2. Unemployment rate for the age group 1574 in rural areas EU in 2015

Źródło: obliczenia własne na podstawie: European Commission, 2016. 
Udział osób bezrobotnych w wieku 15-74 w ogólnej liczbie ludności aktywnej zawodowo na obszarach wiejskich państw Unii Europejskiej cechuje się dość dużą rozpiętością (rys. 2). Wartości analizowanego wskaźnika wahają się od 3,5\% do 24,4\% przy średniej dla UE - 9,7\%. Najwyższy odsetek osób bezrobotnych w wieku 15-74 odnotowano w Hiszpanii (24,4\%), Grecji (20,9\%), Chorwacji (18,3\%), Bułgarii (14,7\%) oraz na Słowacji $(13,5 \%)$. Natomiast najniższy udział osób bezrobotnych odnotowano w Niemczech (3,5\%), Austrii (3,5\%), Wielkiej Brytanii (3,6\%), Czechach $(5,1 \%)$ oraz Holandii (5,4\%). Porównując sytuację w zakresie udziału osób bezrobotnych w wieku 15 74 w ogólnej liczbie ludności aktywnej zawodowo w roku 2015 do 2013 (tab. 1) zaobserwowano korzystną tendencję spadkową. W państwach Unii Europejskiej udział bezrobotnych spadł średnio o 1,7 p.p. Największy spadek odnotowano w Bułgarii - 4,6 p.p., Hiszpanii - 4,3 p.p., na Węgrzech - 3,9 p.p., w Irlandii - 3,8 p.p. oraz na Słowacji 3,4 p.p. Natomiast $w$ trzech państwach odnotowano wzrost udziału osób bezrobotnych w wieku 15-74 w ogólnej liczbie ludności aktywnej zawodowo tj.: w Finlandii - 1,2 p.p., Francji - 0,4 p.p. oraz Austrii - 0,3 p.p.

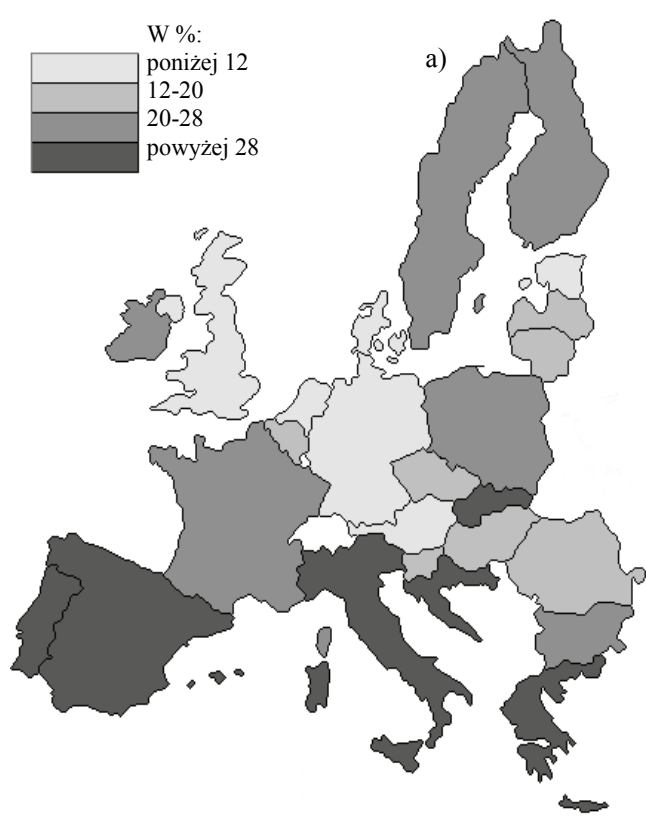

Rys. 3. Udział osób bezrobotnych w wieku 15-24 w ogólnej liczbie ludności aktywnej zawodowo na obszarach wiejskich państw UE w 2015 roku

Fig. 1. Youth unemployment rate for the age group 15-24 in rural areas of EU in 2015

Źródło: obliczenia własne na podstawie: European Commission, 2016.

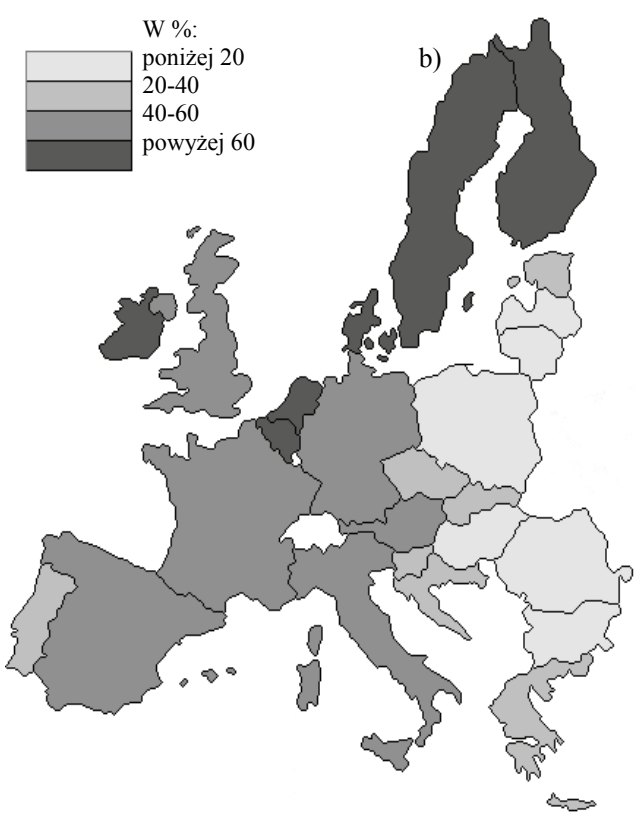

Rys. 4. Produktywność pracy na obszarach wiejskich państw UE w 2013 roku

Fig. 4. Labour productivity in rural areas of EU in 2013

Źródło: obliczenia własne na podstawie: European Commission, 2016.

Udział bezrobotnych w wieku 15-24 w ogólnej liczbie osób aktywnych zawodowo na obszarach wiejskich państw UE charakteryzuje się znacznym zróżnicowaniem od 5.6\% do 
51,5\% przy średniej UE - 22,3\% (rys. 3). Najniższy udział bezrobotnych wśród osób młodych odnotowano na obszarach wiejskich Niemczech (5,6\%), Austrii (7,4\%), Holandii $(9,2 \%)$, Estonii $(11,3 \%)$ oraz Wielkiej Brytanii $(11,5 \%)$. Natomiast zdecydowane większy udział analizowanego wskaźnika odnotowano na obszarach wiejskich Grecji $(51,5 \%)$, Hiszpanii $(48,8 \%)$, Chorwacji $(44,7 \%)$, Włoszech $(36,9 \%)$ oraz Portugalii $(31,9 \%)$. Porównując udział bezrobotnych w wieku 15-24 w ogólnej liczbie osób aktywnych zawodowo w roku 2015 do 2013 (tab. 1) roku we wszystkich państwach Unii Europejskiej odnotowano spadek, średnio o 3,2 p.p. Największy spadek odnotowano na Wegrzech 10,1 p.p., następnie w Grecji - 8,2 p.p., Bułgarii - 8,0 p.p., na Łotwie - 7,2 p.p. oraz w Polsce $-6,8$ p.p. Natomiast w czterech państwach Unii Europejskiej odnotowało wzrost w zakresie analizowanego wskaźnika, tj.: w Finlandi - 2,7 p.p., Francji - 0,6 p.p., Austrii 0,5 p.p. oraz we Włoszech $-0,3$ p.p.

Tabela 1. Wybrane wskaźniki sytuacji na rynku pracy obszarów wiejskich państw Unii Europejskiej w 2015 roku i zmiany w stosunku do 2013 roku

Table 1. Selected indicators of labor market in rural areas of EU countries in 2015 and changes in 2013

\begin{tabular}{|c|c|c|c|c|c|c|c|}
\hline \multirow{2}{*}{ Wyszczególnienie } & \multicolumn{2}{|c|}{$\begin{array}{l}\text { Udział zatrudnio- } \\
\text { nych wśród ludności } \\
\text { w wieku 20-64 }\end{array}$} & \multicolumn{2}{|c|}{$\begin{array}{l}\text { Udział bezrobotnych w } \\
\text { wieku 15-74 wśród } \\
\text { aktywnych zawodowo }\end{array}$} & \multicolumn{2}{|c|}{$\begin{array}{l}\text { Udział bezrobotnych w } \\
\text { wieku } 15-24 \text { wśród } \\
\text { aktywnych zawodowo }\end{array}$} & \multirow{2}{*}{$\begin{array}{c}\text { Produktywność } \\
\text { pracy } \\
2013 \\
\text { (w tys. } \\
\text { EURO/osobę) }\end{array}$} \\
\hline & $\begin{array}{c}2015 \\
(w \%)\end{array}$ & $\begin{array}{l}\text { Zmiany } \\
\text { 2013-2015 } \\
\text { (w p.p.) }\end{array}$ & $\begin{array}{c}2015 \\
(\mathrm{w} \%)\end{array}$ & $\begin{array}{l}\text { Zmiany } \\
\text { 2013-2015 } \\
\text { (w p.p.) }\end{array}$ & $\begin{array}{c}2015 \\
(w \%)\end{array}$ & $\begin{array}{l}\text { Zmiany } \\
\text { 2013-2015 } \\
\text { (w p.p.) }\end{array}$ & \\
\hline Belgium & 69,9 & 0,0 & 6,3 & 0,0 & 18,4 & $-1,4$ & 63,8 \\
\hline Bulgaria & 56,7 & 3,3 & 14,7 & $-4,6$ & 26,9 & $-8,0$ & 8,3 \\
\hline Czech Republic & 74,9 & 2,3 & 5,1 & $-2,0$ & 12,2 & $-6,4$ & 24,6 \\
\hline Denmark & 76,0 & 0,9 & 5,5 & $-0,8$ & 11,7 & $-2,0$ & 72,0 \\
\hline Germany & 81,1 & 0,7 & 3,5 & $-0,6$ & 5,6 & $-0,5$ & 52,4 \\
\hline Estonia & 73,4 & 3,1 & 6,7 & $-2,1$ & 11,3 & $-5,3$ & 23,7 \\
\hline Ireland & 69,7 & 3,2 & 9,3 & $-3,8$ & 23,1 & $-6,4$ & 75,2 \\
\hline Greece & 58,6 & 2,1 & 20,9 & $-2,3$ & 51,5 & $-8,2$ & 33,1 \\
\hline Spain & 58,4 & 3,2 & 24,4 & $-4,3$ & 48,8 & $-6,9$ & 49,5 \\
\hline France & 73,7 & 0,0 & 7,6 & 0,4 & 21,2 & 0,6 & 58,7 \\
\hline Croatia & 57,1 & 3,3 & 18,3 & $-1,9$ & 44,7 & $-6,5$ & 25,6 \\
\hline Italy & 59,6 & 0,8 & 12,0 & $-0,3$ & 36,9 & 0,3 & 56,6 \\
\hline Latvia & 69,9 & 2,8 & 11,2 & $-1,9$ & 19,5 & $-7,2$ & 15,1 \\
\hline Lithuania & 68,2 & 3,2 & 12,4 & $-3,2$ & 17,5 & $-6,5$ & 17,2 \\
\hline Hungary & 65,8 & 5,5 & 7,8 & $-3,9$ & 18,1 & $-10,1$ & 17,6 \\
\hline Netherlands & 79,6 & 0,5 & 5,4 & $-0,3$ & 9,2 & $-1,7$ & 65,1 \\
\hline Austria & 77,6 & $-0,3$ & 3,5 & 0,3 & 7,4 & 0,5 & 58,6 \\
\hline Poland & 66,5 & 2,9 & 8,1 & $-3,0$ & 21,9 & $-6,8$ & 18,1 \\
\hline Portugal & 68,7 & 3,8 & 10,9 & $-3,2$ & 31,9 & $-6,0$ & 29,1 \\
\hline Romania & 65,5 & 1,3 & 6,8 & $-0,3$ & 18,9 & $-1,9$ & 10,5 \\
\hline Slovenia & 69,6 & 1,9 & 8,7 & $-1,1$ & 16,6 & $-5,1$ & 30,9 \\
\hline Slovakia & 66,1 & 2,5 & 13,5 & $-3,4$ & 29,2 & $-7,7$ & 27,6 \\
\hline Finland & 73,0 & $-0,5$ & 8,6 & 1,2 & 24,3 & 2,7 & 63,2 \\
\hline Sweden & 81,9 & 0,7 & 6,6 & $-0,6$ & 20,0 & $-3,2$ & 72,8 \\
\hline United Kingdom & 79,4 & 2,1 & 3,6 & $-1,6$ & 11,5 & $-4,8$ & 43,8 \\
\hline
\end{tabular}

Źródło: European Commission, 2016.

Podobnie jak w przypadku wcześniej analizowanych wskaźników również produktywność pracy okazała się zróżnicowana na obszarach wiejskich państw Unii 
Europejskiej (rys. 4). Wartości analizowanego wskaźnika wahają się od 8,3 tys. EUR/os. do 75,2 tys. EUR/os., natomiast średnia dla państw UE ukształtowała się na poziomie 40,5 tys. EUR/os. Najwyższą produktywność pracy odnotowano na obszarach wiejskich Irlandii (75,2 tys. EUR/os.), Szwecji (72,8 tys. EUR/os.), Danii (72,0 tys. EUR/os.), Holandii (65,1 tys. EUR/os.) oraz Belgii (63,8 tys. EUR/os.). Natomiast najniższą produktywność pracy odnotowano na obszarach wiejskich Bułgarii (8,3 tys. EUR/os.), Rumunii (10,5 tys. EUR/os.), Łotwy (15,1 tys. EUR/os.), Litwy (17,2 tys. EUR/os.) oraz Węgrzech (17,6 tys. EUR/os.).

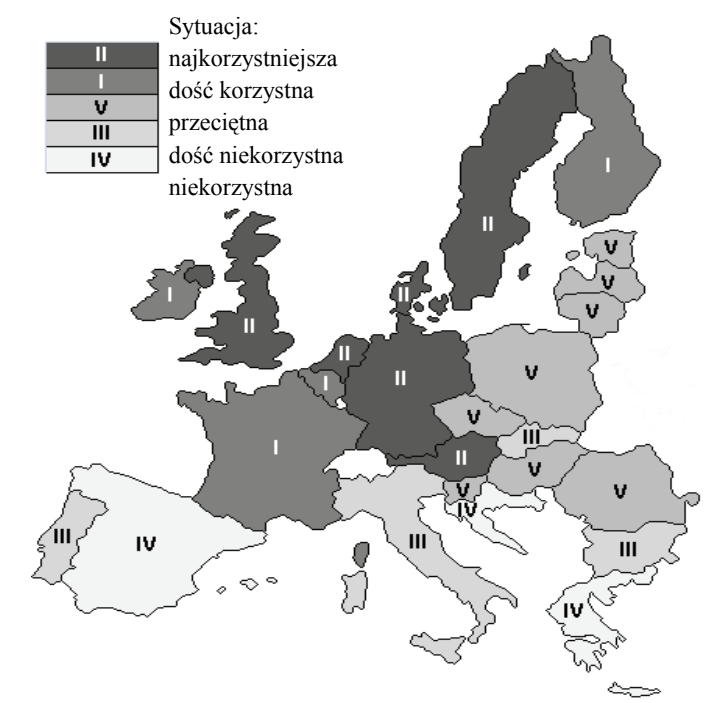

Rys. 5. Zróżnicowanie sytuacji na rynku pracy obszarów wiejskich państw Unii Europejskiej - grupy typologiczne

Fig. 5. Diversity of situation on the labour market of EU countries rural area - groups by type

Źródło: obliczenia własne na podstawie: European Commission, 2016.

Zestawiając cztery omówione wskaźniki podzielono państwa Unii Europejskiej na pięć zróżnicowanych grup (rys. 5, tab. 2). W grupie I znalazły się cztery państwa: Belgia, Irlandia, Francja oraz Finlandia. Cechą wyróżniającą tę grupę państw jest najwyższa produktywność pracy, która ukształtowała się na poziomie 65,2 tys. EUR/os. Ponadto w państwach tej grupy odnotowano dość wysoki udział osób zatrudnionych wśród ludności w wieku 20-64 lata, który ukształtował się średnio na poziomie $71,6 \%$. W subregionie I odnotowano również dosyć niski udział osób bezrobotnych w ogólnej liczbie osób aktywnych zawodowo, który ukształtował się na poziomie 8,0\%. Uzyskane wyniki świadczą o dość dobrej sytuacji na rynku pracy w państwach grupy I.

Grupę II utworzyło sześć państw: Dania, Niemcy, Holandia, Austria, Szwecja oraz Wielka Brytania. Są to państwa cechujące się najwyższym wśród wszystkich grup udziałem osób zatrudnionych wśród ludności w wieku 20-64 lata, który ukształtował się na poziomie $79,3 \%$. Jednocześnie w państwach tej grupy występuje najniższy udział osób bezrobotnych w wieku 15-74 w liczbie osób aktywnych zawodowo, który ukształtował się na poziomie $4,7 \%$. W Subregionie II odnotowano również niski udział bezrobotnych w wieku 15-24 w ludności aktywnej zawodowo, kształtujący się na poziomie 10,9\%. Państwa tworzące grupę II cechują się wysoką produktywnością pracy, która wyniosła 60,8 tys. EUR/os. 
Uzyskane wyniki świadczą o bardzo dobrej sytuacji na rynku pracy obszarów wiejskich państw tworzących grupę II, ja korzystniejszej w porównaniu z innymi grupami.

Tabela 2. Wskaźniki charakteryzujące sytuacje na rynku pracy obszarów wiejskich - według grup typologicznych państw Unii Europejskiej

Table 2. Situation of labor market in rural areas of EU countries - indicators by type group

\begin{tabular}{l|ccccc}
\hline $\begin{array}{l}\text { Wyszcze- } \\
\text { gólnienie }\end{array}$ & $\begin{array}{c}\text { Udział osób za- } \\
\text { trudnionych w } \\
\text { ogólnej liczbie } \\
\text { ludności w wieku } \\
20-64(\mathrm{w} \%)\end{array}$ & $\begin{array}{c}\text { Udział bezrobotnych } \\
\text { w wieku 15-74 w } \\
\text { ogólnej liczbie osób } \\
\text { aktywnych zawodowo } \\
(\mathrm{w} \%)\end{array}$ & $\begin{array}{c}\text { Udział młodych } \\
\text { bezrobotnych }(15-24 \\
\text { lata) w ogólnej } \\
\text { liczbie aktywnych } \\
\text { zawodowo }(\mathrm{w} \%)\end{array}$ & $\begin{array}{c}\text { Produktyw- } \\
\text { ność pracy (w } \\
\text { tys. EUR/os.) }\end{array}$ & $\begin{array}{c}\text { Liczba } \\
\text { jedno- } \\
\text { stek w } \\
\text { grupie }\end{array}$ \\
\hline Grupa I & 71,6 & 8,0 & 21,7 & 65,2 & 4,0 \\
Grupa II & 79,3 & 4,7 & 10,9 & 60,8 & 6,0 \\
Grupa III & 62,8 & 12,8 & 31,2 & 30,4 & 4,0 \\
Grupa IV & 58,0 & 21,2 & 48,3 & 36,1 & 3,0 \\
Grupa V & 69,2 & 8,4 & 17,0 & 19,7 & 8,0 \\
Ogółem & 69,6 & 9,7 & 22,3 & 40,5 & 25.0 \\
\hline
\end{tabular}

Źródło: obliczenia własne.

Grupa III obejmuje cztery państwa: Bułgaria, Włochy, Portugalia oraz Słowacja. W państwach tworzących tę grupę wszystkie wartości analizowanych wskaźników ukształtowały się poniżej (w przypadku stymulant) lub powyżej (w przypadku destymulant) średniej dla całego badanego obszaru. Udział osób zatrudnionych wśród ludności w wieku 20-64 lata osiagnął 62,8\%. Zarówno udział bezrobotnych w wieku 15-74, jak i udział młodych bezrobotnych w wieku 15-24 w ogólnej liczbie aktywnych zawodowo ukształtował się powyżej średniej dla całego badanego regionu. Wartości wskaźników wynosiły odpowiednio $12,8 \%$ oraz $31,2 \%$. Produktywność pracy w państwach tej grupy również charakteryzuje się na niezbyt wysokim poziomem wynoszącym 30,4 tys. EUR/os. Na podstawie wartości uwzględnionych wskaźników sytuację państw subregionu III należy uznać za niezbyt korzystną, jednak lepszą niż w przypadku państw subregionu IV.

Grupę IV utworzyły trzy państwa: Grecja, Hiszpania oraz Chorwacja. W państwach tej grupy odnotowano najniższy wśród badanych grup udział osób zatrudnionych wśród ludności w wieku 20-64 lata, który ukształtował się na poziomie 58\%. W grupie tej odnotowano również najwyższy udział osób bezrobotnych w wieku 15-74 w ogólnej liczbie osób aktywnych zawodowo oraz udział młodych bezrobotnych w wieku 15-24 w ogólnej liczbie osób aktywnych zawodowo. Wskaźniki te charakteryzują się odpowiednio wartościami $21,2 \%$ oraz $48,3 \%$. Ponadto $\mathrm{w}$ państwach tej grupy produktywność pracy ukształtowała się poniżej średniej dla wszystkich krajów, na poziomie 36,1 tys. EUR/os. Na podstawie uzyskanych wyników sytuację na rynku pracy w subregionie IV można uznać za niekorzystną, najsłabszą pośród badanych grup.

Grupa V okazała się najbardziej liczna i skupiła osiem krajów Unii Europejskiej: Czechy, Estonia, Łotwa, Litwa, Węgry, Polska, Rumunia oraz Słowenia. Cechą charakterystyczną państw tej grupy jest zbliżony do wartości średniej dla całego badanego obszaru udział osób zatrudnionych wśród ludności w wieku 20-64 lata (69,2\%). Ponadto na poziomie średniej dla całego regionu ukształtował się również udział osób bezrobotnych w wieku 15-74 oraz udział młodych bezrobotnych w wieku 15-24 w ogólnej liczbie ludności aktywnej zawodowo. Wartości tych wskaźników cechują się odpowiednio 
wartościami na poziomie $8,4 \%$ oraz 17\%. Natomiast produktywność pracy w państwach tej grupy okazała się najniższa wśród wszystkich badanych grup i ukształtowała się na poziomie 19,7 tys. EUR/os. Sytuację na rynku pracy w państwach subregionu V można uznać za średnią.

\section{Dyskusja}

Nawiązując do celu analiz i podstawowych założeń należy artykułu podkreślić, że wielu badaczy potwierdza, iż na rynku pracy obszarów typowo wiejskich sytuacja jest trudniejsza niż w miastach i na terenach podmiejskich (zob. Łabęcki, 2009; MrówczyńskaKamińska, 2013; Kołodziejczak, Kołodziejczak, Pawlak, 2009; Bojnec, 2011; Janeska, Bojnec, 2011). Dotyczy to m.in. państw Europy Środkowej i Wschodniej (grupa V), gdzie udział rolnictwa w strukturze zatrudnienia jest większy. Na uwagę zasługuje fakt, iż na tle pozostałych obszarów wiejskich państw europejskich sytuację krajów Europy Środkowej i Wschodniej można określić jako relatywnie korzystną.

Należy podkreślić, że do problemów rynków pracy Europy Południowej (grupa III i IV) przyczynił się kryzys gospodarczy. Szczególnie w zakresie poziomu bezrobocia kraje te od kilku lat plasują się na ostatnich miejscach pośród wszystkich krajów Unii Europejskiej (European Commission, 2015). Sytuacja ta dotyczy również rynku pracy na obszarach wiejskich, o czym świadczą dość niekorzystna sytuacja państw grupy III i IV.

Warto również zwrócić uwagę, iż w kontekście badań funkcji rolniczej i potencjału produkcyjnego rolnictwa (zob. Baer-Nawrocka, Markiewicz, 2010; Janiszewska, Ossowska, 2016) zdecydowanie lepszą sytuacją na rynku pracy charakteryzują się obszary wiejskie państw o dość wysokim poziomie potencjału produkcyjnego i rozwoju funkcji rolniczej. W państwach wysoko rozwiniętych model gospodarowania w rolnictwie przyczynił się do zmniejszenia zależności tego sektora m.in. od warunków przyrodniczych, jak również do ograniczenia problemu bezrobocia na obszarach wiejskich, co przekłada się na ogólną lepszą sytuację na rynku pracy tych terenów (grupy I i II).

\section{Podsumowanie}

Zgodnie $\mathrm{z}$ celem głównym $\mathrm{w}$ artykule podjęto próbę omówienia zróżnicowania obszarów wiejskich państw Unii Europejskiej na podstawie wybranych wskaźników z zakresu rynku pracy. Przeprowadzono analizę skupień, w wyniku której podzielono badane państwa na pięć grup. Obszary wiejskie państw grupy I i II zlokalizowane głównie w centralnej oraz północnej części Europy charakteryzują się najbardziej korzystną sytuacją w zakresie rynku pracy. Porównując sytuację tych państw do roku 2013 można zauważyć korzystne zmiany w zakresie analizowanych wskaźników. W większości przypadków państwa te odnotowują niewielkie, ale korzystne zmiany na rynku pracy. Państwa grupy III, położone głównie we wschodniej części Europy, charakteryzują się średnią sytuacją pod względem wskaźników charakteryzujących rynek pracy. Jednak porównując sytuację obszarów wiejskich państw tworzących tę grupę pod względem analizowanych wskaźników do roku 2013 można zauważyć, że zmiany są korzystne. Najmniej korzystną sytuacją pod względem sytuacji na rynku pracy charakteryzowały się obszary wiejskie państw położonych w południowej części Europy. Należy jednak podkreślić, że pomimo iż 
pozycja państw grup III i IV nie jest zbyt korzystna pod względem sytuacji na rynku pracy to odnotowały one znaczne korzystne zmiany w zakresie analizowanych wskaźników porównując z sytuacją w roku 2013.

Podsumowując pomimo, że cele przyjęte w programach oraz strategiach (krajowych i zagranicznych) nie przyniosły tak korzystnych efektów jak zakładano, to praktycznie we wszystkich państwach Unii Europejskiej w analizowanym okresie sytuacja na rynku pracy obszarów wiejskich uległa poprawie. Za główną przyczynę nie osiagnięcia zakładanych efektów w zakresie poprawy sytuacji na rynku pracy uznaje się kryzys gospodarczy, który trudno było przewidzieć w czasie opracowywania założeń strategicznych.

\section{Literatura}

Baer-Nawrocka, A., Markiewicz, N. (2010). Zróżnicowanie przestrzenne potencjału produkcyjnego rolnictwa w krajach Unii Europejskiej, Roczniki Nauk Rolniczych, Seria G, 97(4), 9-15.

Bojnec, Š. (2011). Agricultural and Rural Labour Markets in the UE Candidate Countries of Croatia, Former Yugoslav Republic of Macedonia and Turkey, Factor Markets, Working Paper, 6, 1-15.

Council Decision (2010). Council Decision of 21 October 2010 on guidelines for the employment policies of the Member States, 2010/707/EU, 49-51.

European Commission (1994). Growth, competitiveness, employment. The challenges and ways forward into the 21st Country. White Paper, Brussels Luxembourg, s. 133-160.

European Commission (2010). Europe 2020 A strategy for smart, sustainable and inclusive growth, Brussels.

European Commission (2012) Communication from the Commission to the European parliament, the council, the European economic and social committee and the committee of the regions: Towards a job-rich recovery, Strasbourg, 3-23.

European Commission (2015). Labour Market and Wage Developments in Europe 2015, Brussels.

European Commission (2016). Cap context indicators 2014-2020, Agriculture and Rural Development, Brussels.

European Parliament (2010). The Lisbon Strategy 200-2010. An analysis and evaluation of the metods used and results achieved, Brussels.

Frączek, M. (2015). Polityka rynku pracy. Teoria i praktyka. Polskie, Wydawnictwo Ekonomiczne, Warszawa.

GUS (2016). Obszary wiejskie w Polsce w 2014 r., Warszawa-Olsztyn.

Janeska, V., Bojnec, Š. (2011). Rural Labour Market Developments in the Former Yugoslav Republic of Macedonia, Factor Markets, Working Paper, 5, 2-18.

Janiszewska, D., Ossowska, L. (2016). Zróżnicowanie funkcji rolniczej w krajach Unii Europejskiej na podstawie wybranych cech. ZN SGGW Problemy Rolnictwa Światowego, 16(2), 134-144.

Kołodziejczak, W., Kołodziejczak, M., Pawlak, K. (2009). Regionalne zróżnicowanie zasobów pracy w Polsce i polskim rolnictwie w latach 2003 i 2007. Journal of Agribusiness and Rural Development, 4(14), 107-114.

Komunikat Komisji (2005). Wzrost I zatrudnienie - Zintegrowane wytyczne na lata 2005-2008, Bruksela.

Komunikat Komisji (2007). Zintegrowane wytyczne w sprawie wzrostu gospodarczego i zatrudnienia na 20082010 , Bruksela.

Łabędzki, H. (2009). Struktura zatrudnienia ludności rolniczej. Journal of Agribusiness and Rural Development, 3(13), 139-145.

Mrówczyńska-Kamińska, A. (2013). The workforce and its productivity in the food economy of the eu countries, Journal of Agribusiness and Rural Development, 3(29), 85-100.

Parysek, J., Wojtasiewicz, L. (1979). Metody analizy regionalnej i metody planowania regionalnego, PWN Warszawa.

Szaban, J. M. (2016). Rynek pracy w Polsce i w Unii Europejskiej, Difin, Warszawa.

Tocco, B., Davidova, S., Bailey, A. (2012). Commonalities and Differences in Labour Market Developments and Constraints in Different EU Regions. Factor Markets, Working Paper, 22, 1-36. 